International Journal of Instruction e-ISSN: 1308-1470 • www.e-iji.net

Article submission code: 20201105125838

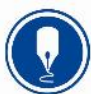

October $2021 \bullet$ Vol.14, No.4

p-ISSN: 1694-609X

pp. $503-528$

Received: 05/11/2020

Revision: 30/03/2021
Accepted: 23/04/2021

OnlineFirst: 11/08/2021

\title{
Organizing Students' Independent Work at Universities for Professional Competencies Formation and Personality Development
}

Milena Tsvetkova

Sofia University, Sofia, Bulgaria, mtsvetkova74@yahoo.com

Natalya Saenko

Moscow Polytechnic University, Moscow, Russia, saenkonat66@rambler.ru

Victoria Levina

Moscow International University, Moscow, Russia, levinavic@ rambler.ru

Larisa Kondratenko

Kuban state agrarian University I. T. Trubilin, Krasnodar, Russia, kondratenkolara@ rambler.ru

\section{Dustnazar Khimmataliev}

Tashkent Institute of Irrigation and Agricultural Mechanization Engineers, Tashkent, Uzbekistan, khimmatalievdus6@ rambler.ru

The purpose of the research is to identify the features of organizing students' independent work, to study the psychological component of this process. The study used a questionnaire for the subjective assessment of the organization of students' independent work and valid psychodiagnostic methods for diagnosing personality characteristics of attitudes towards innovation. The study involved 52 students and 46 teachers from universities in Russia and Bulgaria. It was found that a teacher plays a leading role in organizing the independent work of students, so he/she must be able to quickly and effectively manage this process. There is a need for experience exchange, interaction of teachers within the framework of international conferences and foreign internships to improve the educational process. The study identified insufficient technological and psychological readiness of students and teachers to change the educational process associated with an orientation towards independent work; a low level of creativity of teachers has been found. Internal motivation for innovations in the educational process among students is higher than among teachers, which indicates the dissatisfaction of the former and the inertia of the latter. Among the forms of independent work, routine formal methods predominate, and the indicators of research work are extremely low, which correlates with the data of scientific literature about the prestige of pursuing science among students.

Keywords: virtual simulation, web-based application, multimedia, teaching, learning

Citation: Tsvetkova, M., Saenko, N., Levina, V. Kondratenko, L., \& Khimmataliev, D. (2021). Organizing students' independent work at universities for professional competencies formation and personality development. International Journal of Instruction, 14(4), 503-528. https://doi.org/10.29333/iji.2021.14430a 


\section{INTRODUCTION}

The rapid development of modern society and the technologization of all spheres of life impose new requirements for the professional training of professionals who can easily adapt to rapidly changing conditions and be competitive in the labor market (Khodan, 2013). Modern specialists should not only possess fundamental knowledge, skills and abilities but also be able to creatively approach the solution of extraordinary issues, communicate effectively, easily adapt to the conditions of the modern multidimensional socio-political, market-economic, and information-rich environment (Khodan, 2013). The major condition for effective professional activity in the modern dynamic environment is the competence-based approach (Stolyarenko, 2014). At the same time, competitiveness in any area of professional activity is determined, first of all, by the competitiveness in the field of science and education as a necessary condition for the effective development of professional competences (Sanchez \& Lidawan, 2020). That is, the basic task of training is not the transfer of specific knowledge, skills and abilities but the mastery of the scientific foundations of professional activity and the formation of the necessary competences. The experience of a number of educational institutions shows that today quality education does not depend on a number of classes; first of all, it makes a student an active consumer of knowledge who is able to formulate a problem, analyze its possible solutions, find best results, apply the knowledge gained in specific situations, have a creative approach to the tasks (Sanchez \& Lidawan, 2020). The need to bring up a socially active, creative and independent personality with professional and social mobility, capable of self-development, teamwork, self-study, innovation, a comprehensive treatment of problems and a creative approach to their solution, requires a change in the educational process and its focus on the development of students' skills of independent work, the ability to constantly improve their knowledge, and master professional competences (Skurativska, 2013). Independent work of students, in its modern sense, is a cognitive educational activity, which, being aimed at achieving a specific result, is carried out by students without the direct assistance of a teacher, but under his/her guidance and control, by reducing the required number of classes. The increased requirements for the professional competence of graduates necessitates the development and implementation of qualitatively new forms and methods of higher education aimed at creating an integral system of lifelong learning, expanding the scope of students' independent activities, and shaping their skills of self-organization and selfeducation. The expansion of students' independent work and an increase in its significance are associated with an increase in the amount of work, and, first of all, changes in the relationship between a teacher and a student as equal educational process participants. Thus, a student will independently resolve issues of planning, organization, and control of educational activities, foster independence as a character trait (Skurativska, 2013), as well as critical and design thinking (Koliadenko, 2016). Accordingly, in the context of the competence-based approach, there is a steady trend towards a change in the role of a teacher in the life of a student, a reduction in classes and an increase in the proportion of students' independent work (Kamenez et al., 2019; Vaganova et al., 2019). However, despite the need for the innovative development of the educational sphere, the efforts and funds invested do not always lead to the desired 
result (Romanovska et al., 2020). Therefore, the study of the conditions for ensuring the independent work of students, the analysis of modern approaches and techniques aimed at its organization are an urgent issue.

The object of research is the forms of the educational process at universities.

The subject of the research is the process of organizing students' independent work.

The purpose of the study is to identify the features of the organization of independent work of students, to study the psychological component of this process.

The research objectives are as follows:

1. To analyze the sources of scientific literature on the organization of students' independent work;

2. To reveal the subjective assessment of the technological support and psychological readiness of students and teachers of the process of transition to a new model of the educational process with an increase in the proportion of independent work;

3. To study the psychological component of the process of organizing students' independent work;

4. To develop practical recommendations for improving the independent work of students in the educational process.

The hypothesis of the research is that the organization of students' independent work depends both on technological support and on the psychological readiness of students and teachers to introduce new approaches and methods of educational activity.

This study complements a number of scientific works (Skurativska, 2013; Koliadenko, 2016; Kamenez et al., 2019; Vaganova et al., 2019; Romanovska et al., 2020, etc.) devoted to the problem of organizing students' independent work as a necessary condition for the formation of professionally significant competencies. The novelty of this research lies in the study of the psychological aspects of the organization of independent work of students, the readiness of not only students, but also teachers to accept innovations and work in new conditions. At the same time, to compare the results of psychological testing, a survey was conducted of teachers and students to obtain their subjective assessment of the organization of students' independent work.

\section{Literature Review}

Independent work as a form of educational activity is considered by a number of researchers

Students' independent work is characterized by a planned, cognitive, organizational and methodological focus of educational activities that do not require the direct participation of a teacher; they are performed in accordance with the tasks set by a tutor (Smirnova \& Krasikova, 2018; Smirnova et al., 2017, 2018; Tsyplakova et al., 2016) that are aimed at 
developing the necessary competences in students (Kamenez et al., 2019; Poindexter, 2016; Renninger \& Hidi, 2017). Learning is a way of independent cognitive activity (Stafford-Brizard, 2016; Taylor et al., 2017). Thus, the independent work of students is a way of consolidating knowledge and skills, the development of creative abilities and independent thinking (Vaganova et al., 2019); it is a way of developing independence and ambition, the ability to navigate in theory and practical situations, independently set and creatively solve professional problems (Love, 2018). Therefore, independent work is the highest form of educational activity - it plays a decisive role in the development of personality and ensuring professional activity (Kamenez et al., 2019).

\section{Some studies consider tasks of organizing students' independent work}

In order for graduates to be capable of independent creativity, to be ready to immediately engage in professional activities after graduation, it is necessary to organize the educational process so that it could allow students assimilate a large amount of information and also teach them to independently apply the acquired knowledge (Kamenez et al., 2019). One of the major tools for increasing the efficiency of student learning in the modern educational process is independent work (Kuznetsov \& Katranov, 2016). At the same time, an important condition ensuring success in the development of educational and professional competences, the readiness of graduates for independent scientific and intellectual activities is the readiness for innovative changes of both students and teachers (Kamenez et al., 2019; Noguera et al., 2017; Oakes et al., 2017; Osher et al., 2016a, 2016b, 2018; Pennington et al., 2016). Students' readiness for independent work presupposes the ability to independently manage their educational activities, the development of self-discipline and stable motives for completing assignments (Kamenez et al., 2019), that is, it is necessary to form students' self-management skills, which requires teachers to possess relevant knowledge and skills. In addition to traditional responsibilities, teachers have to expand their range of professional activities performing new roles of an academic consultant, a leader, and a tutor (Kamenez et al., 2019; Markova et al., 2018). An important aspect is also the organization of the independent work of students, which presupposes the availability of appropriate facilities to support learning and the creation of conditions for free communication between the educational process participants (Kamenez et al., 2019). At the same time, each search for the information needed should be ordered, structured, and annotated; the process of extracting the content should be simple and efficient. Science Direct tables, figures, and images, as well as high-quality PDFs, can make it easier to view articles and get information. In addition, the Mendeley Web Importer allows users to save articles from Science Direct to the Mendeley library. The articles can be easily annotated and highlighted in the Mendeley library (Picken \& Springthorpe, 2019).

The role of information and communication technologies in the organization of independent work of students is considered by the following authors

Independent work is a special style of learning; this is a means of involving students in active cognitive activities (Smirnova \& Krasikova, 2018; Smirnova et al., 2017, 2018), which allow them to manage their studies (Makhometa \& Tiahai, 2018). Today the quality of the educational process directly depends on the use of modern information 
and communication technologies that ensure the highest involvement of students in the learning process (Shurygin \& Krasnova, 2016). Independent work is a form of the educational process that, above all, serves as the basis for bringing up a graduate capable of self-development, self-education, innovation (Cantor et al., 2018; Carter \& Darling-Hammond, 2016; Shurygin \& Krasnova, 2016). Distance learning provides relevant educational information, feedback, and interactivity, as well as the ability to organize a variety of educational events and manage educational achievements, which corresponds to the modern paradigm of higher education (Bulaeva et al., 2018; Moroney et al., 2018). In particular, the MOODLE (Modular Object-Oriented Dynamic Learning Environment) platform has communication capabilities that allow a teacher to instantly receive student work, check it, correct mistakes, and send for revision (Bulaeva et al., 2018). The learning management system features, such as highly interactive teaching, a variety of methods and forms of the presentation of educational content, the possibility of drawing up an individual curriculum and other parameters, contribute to an increase in the interest of students, the improvement of skills and the involvement in independent work while simultaneously providing fast and effective management of these processes by a teacher (Denham, 2016; Shurygin \& Krasnova, 2016). Today, the issue of teaching the "growth mindset", the formation of the motivational component of education among students is being actively discussed (Denworth, 2019; Lazonder \& Harmsen, 2016).

Psychological aspects of the organization of independent work of students are considered by the following researchers

Although sociologists consider young people aged 15-24 years as the driving forces of change, including in the field of education (Ho et al., 2015), both students and teachers often lack competences to effectively organize independent work based on a competence-based approach, including in distance learning (Denham, 2016; Shurygin \& Krasnova, 2016). Teachers are not always ready to switch from the traditional role of the leader in the educational process to the role of a mentor that provides information and assistance to students in the process of their self-development (Gregory et al., 2016; Shurygin \& Krasnova, 2016). Nevertheless, properly planned, organized and controlled independent work of students is a prerequisite not only for gaining knowledge, but also for disclosing interests and motives, as well as the formation of professional and personal qualities of students, their skills of self-control, self-esteem and selfdevelopment (Shurygin \& Krasnova, 2016). Inhibition controls, working memory, and cognitive flexibility allow a person to think before acting, resist temptations or impulsive responses, stay focused, reason, solve problems, flexibly adapt to changing requirements or priorities, and see things from a new and different perspective (Korpershoek et al., 2016; Lazonder \& Harmsen, 2016). These skills are of greatest importance to the success in all spheres of life even compared to IQ or socioeconomic status (Diamond \& Daphne, 2016; Hammond, 2016; Lee, 2017); therefore, they should be developed to ensure the success of students in mastering professional competences in the process of independent work. Therefore, today psychological research is the most popular area in pedagogy (Vong \& Yu, 2018). 
Modern students are predominantly active on social networks while being bad at direct communication (Aziziy et al., 2020); however, cooperation is one of the competences that ensure professional success (Aziziy et al., 2020). The development of critical thinking, which focuses on the learning process and information, and contributes to the acquisition of skills to explore, unite, make decisions, create, and apply new knowledge in real situations, is also of importance. In this context, one of the tasks of a teacher is to stimulate the development of students' creative abilities, which involve the use of new educational technologies focused on independent learning and research work of students (Aziziy et al., 2020; Lovekamp et al., 2016). In particular, e-learning based on a virtual worksheet develops the ability to define concepts, allows students to create their own knowledge, which stimulates cognitive processes (Aziziy et al., 2020). Access to incubation resources has a strong impact on the professional intentions of students (Ahmed et al., 2020). At the same time, the key of effective learning in higher education is independent learning guided by teachers (Cukurova et al., 2018; McBurney, 2016). It has been confirmed that guided learning strategies are a more effective approach compared to giving students time to independently find a solution to improve their knowledge and understanding of key concepts (Cukurova et al., 2018); this indicates the leading role of a teacher in the organization of students' independent work. Cultural capital also has a direct positive effect on academic success; it turns out that students from high socioeconomic status families have more developed cultural capital (Meier Jæger \& Møllegaard, 2017). The challenge that unites both problems - the level of teacher qualifications and student training - is a teacher's approach aimed at partnerships, new forms of work and new roles of a teacher (Jackson \& Burch, 2019). Partnership in teaching and learning at universities can enhance the relationship and interdependencies between higher education, society and the economy for the benefit of all stakeholders (Fox \& Diezmann, 2020; Monson, 2017). The importance of the science of learning and development for educational practice is emphasized (Denworth, 2019). Active learning is an important component of human development; however, its mechanisms have not been properly studied. They are developed in childhood, i.e. motivation to learn, curiosity, and the desire to learn new things should be cultivated in early childhood (Begus \& Bonawitz, 2020). This will provide the need to learn and the ability to acquire knowledge independently. However, it should also be considered that the social nature of higher educational institutions defines their dependence on external factors and the state educational policy (Croucher \& Lacy, 2020).

\section{METHOD}

\section{Research Design}

The study consisted of several stages: problem statement, analysis of scientific publications on the research issue, definition of the research object and subject, formulation of the goal, objectives and hypothesis of the study, compilation of a questionnaire and selection of valid psychodiagnostic techniques, formation of a sample of respondents, conducting the study, statistical processing and analysis of the results obtained, discussion of the results, formulation of conclusions, development of practical recommendations (Fig.1). 


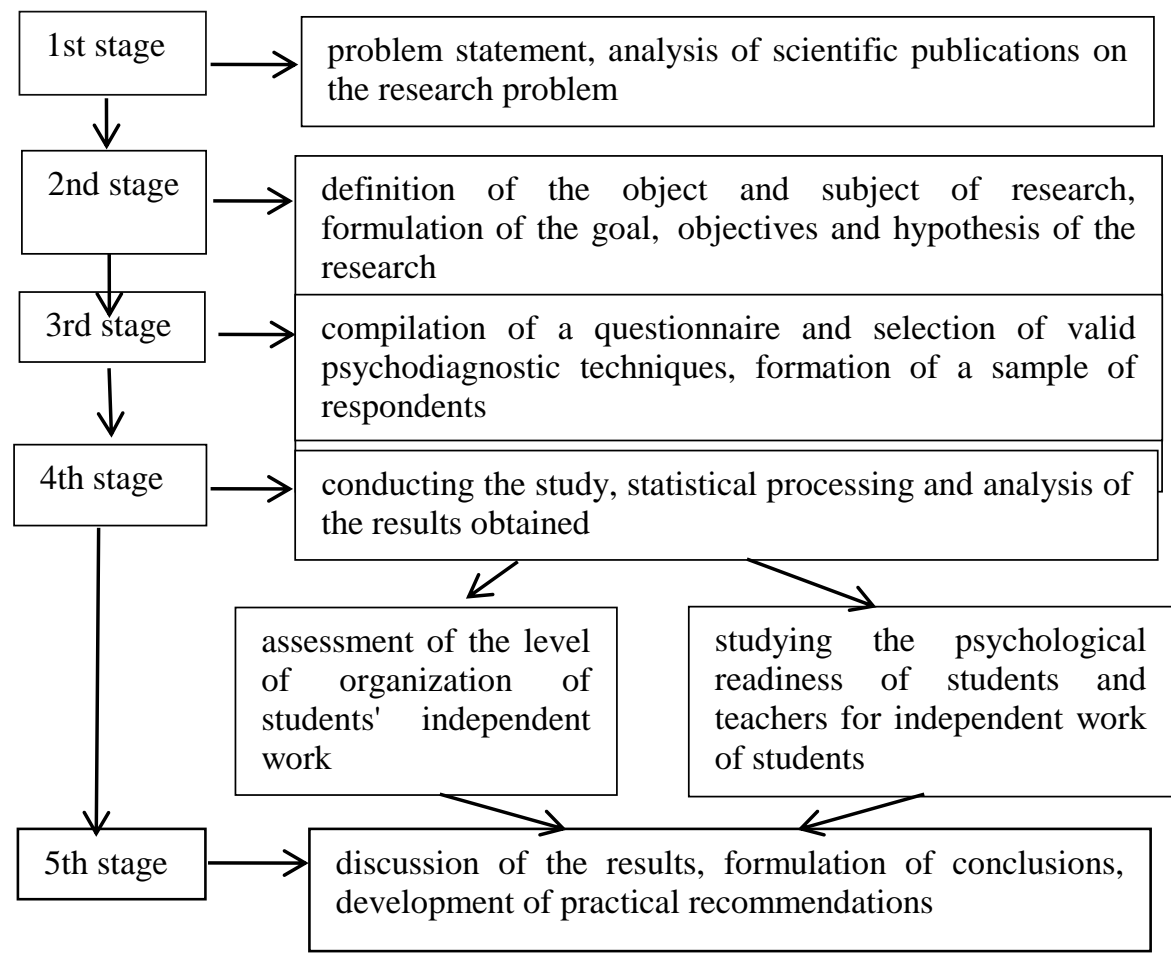

Figure 1

Research stages

The research was conducted, firstly, to assess the level of the organization of students' independent work and the use of modern approaches and techniques, and secondly, to study the psychological readiness of students and teachers for a new paradigm of the educational process involving a competence-based approach with an increase in the proportion of independent work of students. A special questionnaire was developed to address the first issue. This questionnaire was developed taking into account those tasks and problems of organizing students' independent work, which were identified as a result of the analysis of scientific literature. The questionnaire was aimed at assessing two main components: technological support of innovations and psychological readiness of students and teachers for new forms of work. In order to deal with the second issue, the authors introduced psychodiagnostic tests, including valid psychodiagnostic methods (Psychological Tests, n.d.), namely:

- the methodology to diagnose behavior developed by L.I. Wasserman and N.V. Gumenyuk;

- the purpose, means and result methodology by A.A. Karmanova;

- the methodology to diagnose personality motivation to succeed and the methodology to diagnose personality motivation to avoid failures by T. Ehlers; 
- the methodology to diagnose personal readiness for risk by Schubert;

- the methodology to diagnose self-assessment of motivation by D. Marlowe and D. Crowne;

- the methodology to diagnose motivation for success and fear of failure (questionnaire by A.A. Rean);

- the questionnaire for assessing the needs to achieve success;

- the scale for assessing the need for achievement;

- the scale for assessing motivation;

- the methodology testing the ability to use time rationally (Psychological Tests, n.d.).

The purpose, means and result methodology is designed to determine the personal qualities of an individual associated with the activities conducted in a specific period of time (the next 1-2 months) and reflects the basic features of any activity, which is considered as consisting of the three consecutive components (Psychological Tests, n.d.):

- the goal of the activity, which is developed on the basis of the synthesis of a large amount of information; this is the person's vision of the desired future and the final state which he or she wants to achieve;

- the means and resources that a person has to use to achieve the goal;

- the result is the outcome of the activity that the person has achieved.

Motivation for success refers to positive motivation (Psychological Tests, n.d.). Motivation for success determines the desire of a person to achieve something constructive and positive when starting a business. The basis of the activity is the hope for success and the need to achieve success. Such people are usually self-confident and believe in their project; they are responsible, proactive and dynamic. They are characterized by persistence and determination. Motivation for failure refers to negative motivation. The behavior of a person is associated with the need to avoid breakdown, censure, punishment, and failure. In general, motivation for failure is based on the ideas of avoidance and negative expectations. When starting a business, a person is already afraid of possible failure thinking about the ways to avoid the hypothetical failure rather than the ways to achieve success. People motivated to fail are usually characterized by increased anxiety and low self-confidence. They try to avoid important tasks, and when dealing with super-important tasks, they may get into a panic. Situational anxiety becomes extremely high in this case. At the same time, this can be combined with a very responsible attitude to business (Psychological Tests, n.d.). People exceptionally focused on their safety, that is, those having a fear of accidents, are more likely to get into such troubles than those who are highly motivated to succeed. People who are afraid of failure prefer low or, conversely, excessively high risk, when failure does not threaten prestige. The attitude towards protective behavior at work depends on three factors: the degree of the perceived risk; prevailing motivation; the experience of failures at work. There are two circumstances strengthening the attitude towards protective behavior: the first one refers to the situation when the desired result can be obtained without risk and the second one shows that risky behavior leads to an accident. Self-defense mindset, that is, the motivation to avoid failure, is weakened when a safe result is obtained through risky behavior. The willingness to take risks is accompanied 
by low motivation to avoid failure (defense). At the same time, the willingness to take risks decreases with age. More experienced workers are less likely to take risks compared to the inexperienced ones. Women are willing to take risks under more definite conditions than men. Military commanders and business leaders are more willing to take risks than students. The growth of social rejection and the internal conflict contribute to the readiness of a person to take risks. In a group, the willingness to take risks is manifested more strongly than when acting alone and depends on the group's expectations (Psychological Tests, n.d.). The motivation for achievement (success, luck) is the desire to improve results, dissatisfaction with current achievements, persistence in achieving goals, the desire to obtain the result whatever the cost; it is one of the key characteristics of the personality that affects the whole life of a person. Unlike achievement motivation, the approval motivation - the desire to earn the approval of important surrounding people - determines success in activities and accomplishments to a much lesser degree, and sometimes can be an obstacle; however, it significantly affects the quality of relationships with other people. Tests to determine willpower and the ability to use time rationally reflect person's self-management skills (Psychological Tests, n.d.).

As a result of the questionnaire, the features and problems of the organization of independent work of students were revealed, the psychological component of which was further studied using psychodiagnostic tests. At the same time, a comparison was made of the attitude to independent work of students of two groups of respondents: students and teachers, which made it possible to identify general and specific problems of organizing independent work and concretize practical recommendations.

\section{Research Sample}

The sample for the study was formed in a random way since the randomization procedure by randomly assigning respondents to study groups can reduce the bias of the study. In total, 100 sets of written questionnaires and forms of psychodiagnostic tests were prepared, of which 50 sets were distributed to students and teachers of the faculties of jurisprudence and journalism of the Moscow International University and also 50 sets - to students and teachers of the faculties of law and journalism of Sofia University. The choice of these universities and faculties was due to the presence of identical training programs, which made it possible to formulate clear assessment criteria and generalize the results obtained. When the completed questionnaires were checked, two of them turned out to be irrelevant, since one questionnaire was empty and the other did not contain all the answers to the questions, so these respondents were excluded from further research. Thus, a total of 98 people, randomly selected, took part in the study: 46 teachers and 52 students of the first, second and third years of higher educational institutions in Russia and Bulgaria - the faculties of journalism and law of Moscow International University and Sofia University. The survey of respondents was carried out in their native language; for this, two variants of the questionnaire, identical in meaning, were used: in Russian and in Bulgarian. With regard to psychological tests, a valid Russian-language version was used since the respondents from Bulgaria had sufficient 
command of Russian in order to understand the questions of these tests and give appropriate answers to them.

The authors did not distinguish between the respondents depending on age, gender and country, since students and teachers were compared in their attitude to independent work as a form of study, and therefore the main criterion for allocation into the study groups was the status of the respondent - student or teacher.

The research results were processed on medstatistic.ru. The reliability of the results obtained was assessed by the independent t-test. The correlation coefficient of the indicators of different methods and their scales was also calculated.

\section{Data Analysis}

Summary tables provide general results demonstrated by two educational institutions; it was revealed that there were no significant differences between the answers of the respondents from Bulgarian and Russian universities, thus, one can notice similarity of problems related to the educational process structure and its reform in these countries. At the same time, it should be considered that the research conducted at other faculties or in other countries may reflect different results showing the specifics of the specialty, the peculiarities of the educational system or the mentality of the country. Therefore, taking into account the identified common problems of organizing students' independent work, it is recommended to consider the present research as a pilot study, which could be expanded through attracting a larger sample of respondents and conducted at various faculties and in different countries. This can help one to identify not only the existing difficulties but also the best approaches to the organization of students' independent work. In addition, some of the psychodiagnostic techniques used in the study took into account the gender characteristics of the respondents; however, the authors described summarized data in the tables and did not include gender specifics as they were not stated as study objectives.

\section{Ethical Issues}

When studying the problems of organizing students' independent work, the authors expected the respondents to give objective answers to the questions of the questionnaire; therefore, the authors tried to ensure maximum anonymity and confidentiality. Nevertheless, it was revealed that some teacher participants strove to improve their results, which was associated with the desire to show their educational institution in the most favorable light. Despite the anonymity of the study, the response bias of some students was associated with the fear that criticism about the educational process structure would negatively affect their academic performance.

\section{FINDINGS AND DISCUSSION}

First of all, the authors conducted a survey of respondents about the organization of independent work in the educational process. The results are shown in Table 1. 
Table 1

Organizational support for students' independent work

\begin{tabular}{|c|c|c|c|c|c|c|}
\hline \multirow[t]{2}{*}{ Question } & \multicolumn{2}{|l|}{ Teachers } & \multicolumn{2}{|l|}{ Students } & \multirow[t]{2}{*}{ t-test } & \multirow[t]{2}{*}{$\mathrm{p}$} \\
\hline & $\begin{array}{l}\text { absolute } \\
\text { value }\end{array}$ & $\%$ & $\begin{array}{l}\text { absolute } \\
\text { value }\end{array}$ & $\%$ & & \\
\hline $\begin{array}{l}\text { Availability of the modern IT infrastructure in } \\
\text { the educational institution }\end{array}$ & 34 & 88.5 & 36 & 69.2 & 136.47 & $<0.05$ \\
\hline $\begin{array}{l}\text { Availability of technical support for the } \\
\text { teacher in the educational process }\end{array}$ & 27 & 58.7 & 33 & 63.5 & 33.94 & $<0.05$ \\
\hline $\begin{array}{l}\text { Free access to the discipline materials for } \\
\text { teachers providing the curriculum }\end{array}$ & 22 & 47.8 & 20 & 38.5 & 65.76 & $<0.05$ \\
\hline $\begin{array}{l}\text { Free access to the discipline materials for } \\
\text { students }\end{array}$ & 16 & 34.8 & 18 & 34.6 & 1.41 & $>0.05$ \\
\hline Use of educational websites & 18 & 39.1 & 25 & 48.1 & 63.64 & $<0.05$ \\
\hline $\begin{array}{l}\text { A logical connection between disciplines and } \\
\text { a logical study sequence }\end{array}$ & 41 & 89.1 & 28 & 53.8 & 249.61 & $<0.05$ \\
\hline $\begin{array}{l}\text { Possession of basic knowledge and skills to } \\
\text { start studying the discipline }\end{array}$ & 23 & 50.0 & 21 & 40.4 & 70.71 & $<0.05$ \\
\hline Personalized learning experience & 27 & 58.7 & 17 & 32.7 & 183.85 & $<0.05$ \\
\hline $\begin{array}{l}\text { The use of classroom teaching to provide the } \\
\text { student with an integrated learning experience }\end{array}$ & 25 & 54.3 & 15 & 28.8 & 180.31 & $<0.05$ \\
\hline $\begin{array}{l}\text { Clearly defined learning outcomes of the } \\
\text { course and their compliance with the } \\
\text { objectives of the educational program }\end{array}$ & 36 & 78.2 & 12 & 23.1 & 389.62 & $<0.05$ \\
\hline Computer and digital literacy & 38 & 82.6 & 49 & 94.2 & 82.02 & $<0.05$ \\
\hline $\begin{array}{l}\text { Intrinsic motivation for innovation in the } \\
\text { educational process }\end{array}$ & 25 & 54.3 & 36 & 69.2 & 105.36 & $<0.05$ \\
\hline Intrinsic motivation for independent work & 21 & 45.7 & 19 & 36.5 & 65.05 & $<0.05$ \\
\hline $\begin{array}{l}\text { Feedback (comments on the characteristics of } \\
\text { the completed assignment, suggestions for } \\
\text { next steps, timeliness) }\end{array}$ & 23 & 50.0 & 24 & 46.2 & 26.87 & $<0.05$ \\
\hline Clear assessment criteria & 37 & 80.4 & 32 & 61.5 & 133.64 & $<0.05$ \\
\hline Completing assignments & 33 & 71.7 & 37 & 71.2 & 0.71 & $>0.05$ \\
\hline Completing test tasks & 39 & 84.8 & 42 & 80.8 & 28.28 & $<0.05$ \\
\hline Summary report & 41 & 89.1 & 48 & 92.3 & 22.63 & $<0.05$ \\
\hline Research & 9 & 19.7 & 5 & 9.6 & 71.42 & $<0.05$ \\
\hline Making multi-media presentations & 16 & 34.8 & 12 & 23.1 & 82.73 & $<0.05$ \\
\hline Solving creative tasks & 11 & 23.9 & 6 & 11.5 & 87.62 & $<0.05$ \\
\hline Preliminary study of educational materials & 24 & 52.2 & 8 & 15.4 & 260.22 & $<0.05$ \\
\hline Taking notes & 40 & 87.0 & 50 & 96.2 & 65.05 & $<0.05$ \\
\hline Completing individual tasks & 27 & 58.7 & 31 & 59.6 & 6.36 & $<0.05$ \\
\hline TOTAL & 46 & 100 & 52 & 100 & & \\
\hline Correlation coefficient & 0.761 & & & & 5.497 & $<0.05$ \\
\hline
\end{tabular}

The authors note the insufficient technological and psychological readiness of both students and teachers to the change in the educational process and new forms of work. At the same time, teacher and student assessments differ significantly in a number of organizational issues. Thus, $88.5 \%$ of teachers indicate the availability of a modern IT infrastructure in the educational institution while only $69.2 \%$ of student respondents agree with this. It can be presumed that teachers tried to show their educational institution in the most favorable light or the students did not have enough information 
about the innovations. In addition, both groups perceive information technologies as fast-improving and what teachers find to be quite modern may be perceived by students as not new enough. The indicator of computer literacy among students is much higher than that among teachers; this is a paradox that the older generation has professional knowledge and experience but there is less demand for them compared to the knowledge of the younger generation acquired independently from the Internet. Therefore, constant improvement of teacher qualifications aimed at mastering modern technologies is of great importance. This is a global problem and the ways of its solution are described in the state programs of many countries. In particular, today the reform of the education system of Uzbekistan (National database of legislation, 2019) is aimed at the development of technological capabilities of universities, digital educational and scientific processes, which creates new requirements for teaching staff (Khamdullaeva \& Garibyan, 2018). Therefore, the Ministry of Higher and Secondary-Specialized Education of the Republic of Uzbekistan has developed measures for the improvement of higher education system, which are aimed at effective retraining and advanced training of teachers of higher educational institutions with the involvement of foreign internships (Ruzieva, 2018). At the same time, the total number of teachers whose activities are characterized by a low and unsatisfactory level of creativity significantly exceeds the number of teachers with a high level of creative development (Turkmenova \& Babanov, 2020), which is confirmed by the low motivation of teachers to innovate in the educational process and insufficient motivation of students for independent work revealed in the present study. That is, teachers who are not creatively active do not contribute to the creativity of students. Accordingly, students also lack motivation for independent work expecting teachers to give them ready-made instructions and solutions. At the same time, in the present study teachers much more often noted the presence of research activities and creative assignments than students; however, in general, these indicators were low in both groups of respondents. The results obtained allow the authors to conclude that note-taking, summary reports, as well as independent assignments and test tasks prevailed among the forms of independent work while independent preliminary study of educational materials, preparation of multimedia presentations, solving creative problems and, in particular, conducting research work were used much less often. Thus, the results of the current research directly correlate with the data of scientific literature, and the focus is placed on the low prestige of creative work as one of the reasons for this (Turkmenova \& Babanov, 2020). The creation of favorable conditions for the development of creative pedagogy involves a number of practical measures, including: consideration of creative capabilities of teachers when recruiting them, rational use of working hours, comprehensive methodological support for creative pedagogical activity, maintenance of a safe moral and psychological climate in the team, improvement of teachers' working conditions and leisure time (Turkmenova \& Babanov, 2020). Active teaching methods, which include independent work, are aimed not only at the assimilation of knowledge by students and the formation of professional skills and abilities, but also at the development of creative and communicative abilities of the individual, the formation of a personal approach to the emerging problem (Abdullaeva, 2018). It should also be emphasized that the level of creativity directly depends on the degree of use and mastery of information and 
communication technologies (Balatsky, 2016; A. Chirva \& O. Chirva, 2018). The present study highlights the low rate of the use of educational websites, which may be due to poor qualifications of users, lack of their awareness, the quality of the websites, and the relevance of the information provided. On the other hand, it should be taken into account that the quality of education is largely determined by the quality of the person being taught, that is, "the root of the educational process is the learners themselves rather than their formal attributes" (Mukova, 2016). According to Bulgarian researchers, the problem is that more than half of students have incorrect attitudes. They are motivated to achieve an inertial goal - they want to receive a decent reward while not working hard - instead of a goal to work well to receive a decent remuneration. Due to this fact there is almost no positive competition between students that could lead to their professional development (Mukova, 2016). At the same time, it is noted that one of the significant disadvantages of distance education is the lack of direct communication between a student and a teacher (Mukova, 2016). However, the results of the present study conversely indicate great potential of learning based on an electronic learning platform to increase the interactivity of classes and make them more personalized. Despite this fact, there is also a concern that the elimination of classroom consulting makes the learning process optional (Mukova, 2016). The problem is that regardless of the form of education, university students are only interested in acquiring specific skills related to their occupation - "craft skills" - while the issue of science intensity of the academic discipline does not bring income (Fedorov et al., 2017; Mukova, 2016). This is also confirmed by the results of the present survey, which revealed the low motivation of students and teachers to use independent activities; and the intrinsic motivation for innovations in the educational process among students turned out to be higher than that among teachers, which indicates the dissatisfaction of the former and the inertia of the latter. In this regard, it is emphasized that assignment can be considered independent if there are unique rather than standard questions and answers (Mukova, 2016). In addition, a teacher should properly structure the educational material, be able to maintain a good relationship with students, have feedback from them, create conditions for active and independent participation of students in the educational process, thereby ensuring the effectiveness and quality of teaching (Garnevska, 2018). The effectiveness of distance education assumes the availability of funds allocated for the development of educational and methodological material and individual learning (no more than ten students per teacher), significant differentiation and specialization of teacher work, appropriate technical facilities and depends on the optimal interaction between the teacher and students. An important aspect of this interaction is the organization of students' independent work, which is both a teaching method and a feedback regulator (Altukhova, 2014).

Having analyzed the problematic aspects of organizing students' independent work, the authors have selected valid psychodiagnostic techniques (Psychological Tests, n.d.) aimed at studying goal-setting, focus on achieving results, motivational aspect of the educational activity, willpower, and self-management skills. The results of the study are presented in Tables 2-4. 
Table 2

The results of the comparative study of teachers and students according to the purpose, means and result methodology

\begin{tabular}{|c|c|c|c|c|c|c|}
\hline \multirow[t]{2}{*}{ Scores } & \multicolumn{2}{|l|}{ Teachers } & \multicolumn{2}{|l|}{ Students } & \multirow[t]{2}{*}{ t-test } & \multirow[t]{2}{*}{$\mathrm{p}$} \\
\hline & absolute value & $\%$ & absolute value & $\%$ & & \\
\hline \multicolumn{7}{|l|}{ Purpose } \\
\hline From -9 to -5 & 3 & 6.5 & 9 & 17.3 & 76.37 & $<0.05$ \\
\hline From -4 to +4 & 8 & 17.4 & 27 & 51.9 & 243.95 & $<0.05$ \\
\hline From +5 to +9 & 35 & 76.1 & 16 & 30.8 & 320.32 & $<0.05$ \\
\hline TOTAL & 46 & 100 & 52 & 100 & & \\
\hline Correlation coefficient & 0.020 & & & & 0.020 & $>0.05$ \\
\hline \multicolumn{7}{|l|}{ Means } \\
\hline From -9 to -2 & 12 & 26.1 & 8 & 15.4 & 75.66 & $<0.05$ \\
\hline From -1 to +2 & 15 & 32.6 & 21 & 40.4 & 55.15 & $<0.05$ \\
\hline From +3 to +6 & 17 & 37.0 & 17 & 32.7 & 30.41 & $<0.05$ \\
\hline From +7 to +9 & 2 & 4.3 & 6 & 11.5 & 50.91 & $<0.05$ \\
\hline TOTAL & 46 & 100 & 52 & 100 & & \\
\hline Correlation coefficient & 0.795 & & & & 1.856 & $<0.05$ \\
\hline \multicolumn{7}{|l|}{ Result } \\
\hline From -9 to -5 & 2 & 4.3 & 18 & 34.6 & 214.25 & $<0.05$ \\
\hline From -4 to +4 & 35 & 76.1 & 33 & 63.5 & 89.10 & $<0.05$ \\
\hline From +5 to +9 & 9 & 19.6 & 1 & 1.9 & 125.16 & $<0.05$ \\
\hline TOTAL & 46 & 100 & 52 & 100 & & \\
\hline Correlation coefficient & 0.715 & & & & 1.023 & $<0.05$ \\
\hline
\end{tabular}

As for the development of the activity purpose, that is, a more or less clear vision of the desired future, the overwhelming majority of teachers and about a third of students showed an optimal result; the motives for goal-setting and activities are generally systematic and hierarchical when a person sets real goals and is determined to achieve them. The person can explain the expediency of almost any activity performed. The person is not prone to wasting time. Decisiveness is associated with the ease of setting goals rather than suspiciousness. At the same time, half of the student respondents demonstrated average values on this scale; this indicates that their goals are unstable and sometimes unjustified; not all reasonable actions are expedient and there is a tendency to waste time. When dealing with difficulties in selecting a goal, such a person easily uses external advice, is ready to accept a goal from the outside, and in order to perform an activity, they always need willpower to "get thoughts together" (Psychological Tests, n.d.). A fairly large percentage of student participants (17.3\%) showed low scores on the goal-setting scale indicating that they are in a very frustrated state, which is reflected through the inability to set constructive goals. The motives for the activity are not systematic and hierarchical. A person confines to "micro-goals" determined by the current situation or focuses on setting global goals rather than real goals and achieving significant results. The latter is manifested in the search for the so-called "meaning of life" (Psychological Tests, n.d.). The problems of goal-setting were also found in some teachers, which indicates either their psychological immaturity or is indirect evidence of professional burnout; this issue requires a further in-depth study. As for students, the immaturity of their ability to clearly formulate goals of their educational activities is a reflection of the immaturity of thinking, lack of independence, dependence on the 
influence of the micro-society. In this context, the emphasis on independent activities in the learning process, if properly organized, will contribute to the development of the ability to formulate goals, otherwise it will become formal. That is, students should be taught the algorithm for performing independent work and the number of creative research tasks should be gradually increased. Some teachers believe that junior students are not ready to conduct research; thus, they reduce independent tasks related to notetaking and making reports. However, the authors believe that such routine work does not contribute to the development of the necessary competences in the student and leads to the formalization of the learning process while the gradual involvement of students in the creative process of scientific research under the guidance of a teacher is an effective means of forming important professional and personal qualities of thinking, disclosing the creative potential of the individual, and increasing the passion for the learning process and interest in the occupation.

The authors obtained interesting results on the Means scale - half of the teachers, as well as students, showed low and below average results. Low results on this scale indicate that a person experiences a constant lack of means to achieve their goals. This is typically manifested in low energy potential, the predominance of the parasympathetic component of the autonomic nervous system, conformity, strong dependence on the situation or other people (primarily on their opinion), suggestibility, an abundance of psychological complexes, which do not allow the use of internal potential to the fullest. The respondent scores below average if they periodically encounter difficulties in choosing the means (this refers to psychological barriers). The reason for restraint is often the lack of a constructive and achievable goal. Such behavior is also determined by a set of reasons that can be called fear of self-expression. The attitudes of the subject are dominated by energy-saving motives and the behavior lacks spontaneity (Psychological Tests, n.d.). Nevertheless, more than a third of teachers and about a third of students showed the optimal result on the Means scale indicating sufficient freedom in the choice of means when the behavior is as spontaneous as the situation requires. There is a fairly good energy potential and a balance between sympathetic and parasympathetic nervous system. A person is neither aggressive nor conforming; the behavior is neither provocative nor blocked by complexes, suspiciousness, and negativism (Psychological Tests, n.d.). However, it should be noted that a number of respondents showed the maximum scores on this scale, which reflects the presence of excessively spontaneous behavior. Thus, a person does not seek help from others but prefers to lead them. The subject does not pay attention to the standards of behavior and often acts contrary to them; the person is characterized by aggressiveness which can be active and passive (Psychological Tests, n.d.). At the same time, there were $11.5 \%$ of such respondents among students, which shows the need for appropriate psychological and pedagogical correction. The identification of this indicator among teachers $(4.3 \%)$ shows the need to work with the staff of higher educational institutions.

As for the Result scale, the majority of teachers and more than half of the students surveyed demonstrated optimal scores; this indicates that they critically evaluate the results of their activities - they neither overestimate nor underestimate the results while impartially assessing other people and events; their personal growth is generally 
dynamic (Psychological Tests, n.d.). At the same time, a fairly large percentage of teachers scored high on this scale, which reflects their tendency to underestimate the results of their activities. Such people are characterized by rigidity and excessive criticality. They assess the behavior of other people with criticism and disapproval. Perseverations are a vivid manifestation of rigidity - repeated and obsessive repetitions. The subject repeats the same phrase and performs the same action. The person rarely experiences strong emotions - the most spectacular results do not bring intense pleasure or grief (Psychological Tests, n.d.). These personal characteristics of a teacher cannot make teaching creative and effective, which raises the question about professional suitability in terms of meeting the requirements of modern higher education. At the same time, such indicators may indirectly reflect professional burnout. That is, further research may be aimed at the study of the correlation between the indicators of the Purpose, Means and Result methodology and manifestations of professional burnout. Interestingly, a number of teachers showed maximum indicators on the Result scale while a third of students, on the contrary, demonstrated minimum values, which indicates a tendency to overestimate the result of their activities. Luck causes paroxysm of intense fun; failure provokes inadequate grief. Minor events can cause real shock. The person seems to be in a state of chronic transition and trance. The personal growth of the subject is unpredictable and random in many respects; there is often increased anxiety and interest in one's own inner world (Psychological Tests, n.d.). Such indicators are evidence of the psychoemotional immaturity of the respondents and indicate the need for appropriate psychological and pedagogical support.

Generally, in contrast to teachers, students have more pronounced problems of setting goals, choosing means and assessing the result of educational activities; this should be taken into account when drawing up curricula and choosing forms of independent work. It also indicates the need for appropriate psychological and pedagogical correction. Despite the fact that the majority of teachers scored optimal points, a significant number of them demonstrated deviations from the average score, which may indicate professional burnout and raise questions about professional suitability and the need for an appropriate personnel policy in higher educational institutions as it is personal factors that can be a serious obstacle to the introduction of innovative forms of the educational process.

When analyzing the results of the study of the motivation for success and the fear of failure according to the questionnaire by A.A. Rean, it can be seen that teachers have above average and high scores while students, on the contrary, demonstrate average and low values (Tab. 3). That is, students are more often characterized by the fear of failure or motivation for failure while teachers have positive motivation - they are focused on achieving something constructive and positive, hope for success and the need to achieve success. Such people are usually self-confident, proactive, and persistent in achieving goals. Negative motivation spawns fear of possible failure, increases anxiety, and reduces self-confidence; this is observed in advance and can be combined with a very responsible attitude to business (Psychological Tests, n.d.). 
Table 3

Results of the comparative study of teachers and students using the motivation for success and fear of failure methodology (questionnaire by A.A. Rean)

\begin{tabular}{|c|c|c|c|c|c|c|}
\hline \multirow[t]{2}{*}{ Scores } & \multicolumn{2}{|l|}{ Teachers } & \multicolumn{2}{|l|}{ Students } & \multirow[t]{2}{*}{ t-test } & \multirow[t]{2}{*}{$P$} \\
\hline & absolute value & $\%$ & absolute value & $\%$ & & \\
\hline $1-7$ & 5 & 10.9 & 12 & 23.1 & 86.27 & $<0.05$ \\
\hline $8-9$ & 7 & 15.2 & 19 & 36.5 & 150.61 & $<0.05$ \\
\hline $11-13$ & 11 & 23.9 & 6 & 11.5 & 87.68 & $<0.05$ \\
\hline $14-20$ & 23 & 50.0 & 15 & 28.8 & 149.91 & $<0.05$ \\
\hline TOTAL & 46 & 100 & 52 & 100 & & \\
\hline Correlation coefficient & 0.959 & & 0.972 & & & \\
\hline
\end{tabular}

Students often associate negative motivation with the need to speak in front of the class, that is, with the fear of public speaking, while distance learning removes this problem. At the same time, distance learning does not solve the essence of the problem. Therefore, such cases require psychological and pedagogical correction based on an individual approach to each student, which involves the appropriate qualifications of the teacher. For example, the structure of independent tasks can be aimed at the gradual transformation of the student's negative attitudes to positive ones; thus, there is a need for self-presentation and public presentation of one's own achievements, which may reflect the need for approval. The results of the study of approval, motivation, willingness to take risks, and self-management skills of students and teachers are described in the table below.

In contrast to teachers, students predominantly try to avoid failure and are motivated to defend, but at the same time, this is paradoxically combined with the willingness to take risks (Tab. 4). Failure avoidance may refer to academic performance while the willingness to take risks affects other spheres of life and is associated with underdeveloped self-preservation instinct, which manifests itself in hobbies related to extreme sports or other similar behavior. Teachers are not as risky as students, but more adaptable to failures. At the same time, teachers are much more motivated to succeed in comparison with students. Students are more focused on achievements, that is, the desire to achieve a result at all costs, than on success as they are guided by the desire to avoid failure rather than the desire to succeed. At the same time, most of them need approval they seek to earn a positive assessment of important people around them - without thinking about the reasons for this. This also indicates the need for psychological correction. This was described by the Bulgarian researchers who noted the problem of personal self-improvement in the process of studying at university (Mukova, 2016). 
Table 4

Results of the comparative study of the level of motivation, risk, and self-management of teachers and students

\begin{tabular}{|c|c|c|c|c|c|c|}
\hline \multirow[t]{2}{*}{ Scores } & \multicolumn{2}{|l|}{ Teachers } & \multicolumn{2}{|l|}{ Students } & \multirow[t]{2}{*}{ t-test } & \multirow[t]{2}{*}{$\mathrm{P}$} \\
\hline & absolute value & $\%$ & absolute value & $\%$ & & \\
\hline \multicolumn{7}{|c|}{ Motivation to avoid failure } \\
\hline $2-10$ & 19 & 41.3 & 9 & 17.3 & 169.71 & $<0.05$ \\
\hline $11-16$ & 15 & 32.6 & 12 & 23.1 & 67.18 & $<0.05$ \\
\hline $17-20$ & 9 & 19.6 & 18 & 34.6 & 106.07 & $<0.05$ \\
\hline$>20$ & 3 & 6.5 & 13 & 25.0 & 130.81 & $<0.05$ \\
\hline TOTAL & 46 & 100 & 52 & 100 & & \\
\hline \multicolumn{7}{|l|}{ Motivation for success } \\
\hline $30-75$ & 6 & 13.0 & 31 & 59.6 & 329.51 & $<0.05$ \\
\hline $76-164$ & 18 & 39.2 & 9 & 17.3 & 154.86 & $<0.05$ \\
\hline $165-210$ & 22 & 47.8 & 12 & 23.1 & 174.66 & $<0.05$ \\
\hline TOTAL & 46 & 100 & 52 & 100 & & \\
\hline Correlation coefficient & -0.973 & & -0.500 & & & \\
\hline \multicolumn{7}{|c|}{ Motivation for achievement } \\
\hline $2-10$ & 6 & 13.0 & 9 & 17.3 & 30.41 & $<0.05$ \\
\hline $11-15$ & 18 & 39.2 & 26 & 50.0 & 76.37 & $<0.05$ \\
\hline $16-19$ & 22 & 47.8 & 17 & 39.7 & 57.28 & $<0.05$ \\
\hline TOTAL & 46 & 100 & 52 & 100 & & \\
\hline Correlation coefficient & 1.000 & & -0.979 & & & \\
\hline \multicolumn{7}{|l|}{ Motivation for approval } \\
\hline $2-10$ & 2 & 4.3 & 3 & 5.8 & 10.61 & $<0.05$ \\
\hline $11-15$ & 17 & 37.0 & 10 & 19.2 & 125.87 & $<0.05$ \\
\hline $16-19$ & 27 & 58.7 & 39 & 75.0 & 115.26 & $<0.05$ \\
\hline TOTAL & 46 & 100 & 52 & 100 & & \\
\hline Correlation coefficient & 1.000 & & 0.360 & & & \\
\hline \multicolumn{7}{|l|}{ Readiness to take risks } \\
\hline$<-30$ & 18 & 39.1 & 4 & 7.7 & 222.03 & $<0.05$ \\
\hline From -10 to +10 & 22 & 47.8 & 27 & 51.9 & 28.99 & $<0.05$ \\
\hline$>+20$ & 6 & 13.1 & 21 & 40.4 & 193.04 & $<0.05$ \\
\hline TOTAL & 46 & 100 & 52 & 100 & & \\
\hline Correlation coefficient & -0.630 & & 0.421 & & & \\
\hline \multicolumn{7}{|l|}{ Willpower test } \\
\hline$<14$ & - & - & 18 & 34.6 & 244.66 & $<0.05$ \\
\hline $15-25$ & 33 & 17.7 & 24 & 46.2 & 201.59 & $<0.05$ \\
\hline $26-38$ & 23 & 50.0 & 9 & 17.3 & 231.22 & $<0.05$ \\
\hline$>38$ & - & - & 1 & 1.9 & 13.44 & $<0.05$ \\
\hline TOTAL & 46 & 100 & 52 & 100 & & \\
\hline \multicolumn{7}{|c|}{ The ability to use time rationally (self-management skills) } \\
\hline $0-15$ & 3 & 6.5 & 11 & 21.2 & 103.94 & $<0.05$ \\
\hline $16-20$ & 5 & 10.9 & 23 & 44.2 & 235.47 & $<0.05$ \\
\hline $21-25$ & 21 & 45.7 & 12 & 23.1 & 159.81 & $<0.05$ \\
\hline $26-30$ & 17 & 36.9 & 6 & 11.5 & 179.61 & $<0.05$ \\
\hline TOTAL & 46 & 100 & 52 & 100 & & \\
\hline Correlation coefficient & 0.575 & & 0.853 & & & $<0.05$ \\
\hline
\end{tabular}

The willpower test revealed a striking difference between students and teachers. Thus, the high teachers' scores indicated fairly strong willpower, realistic and balanced 
actions, responsible behavior, and the objectivity of self-esteem while more than a third of the students showed poor volitional powers and there was a biased self-assessment of volitional qualities in one of the cases (Psychological Tests, n.d.). The teachers were also characterized by a high level of self-management skills and the ability to rationally use their time while most students found it difficult to schedule their activities. The students depend on external circumstances, cannot make a list of priority goals, and adhere to the plan; when trying to manage their time, they are often inconsistent and poorly motivated to achieve success (Psychological Tests, n.d.).

Independent work of students is a strategy of guided learning and is an effective way of forming professional competencies of students, due to the high interactivity of the educational process, a variety of forms and methods of presenting educational material, the possibility of drawing up an individual curriculum to increase students' interest in the subject under study.

The teacher plays a leading role in organizing the independent work of students, so he/she must be able to quickly and effectively manage this process.

The global nature of the problem of changing the paradigm of education with an emphasis on independent work, which is associated with a decrease in the number of classes, the introduction and expansion of distance learning, actualizes the need to study the experience of different countries, the interaction of teachers in the framework of international conferences and foreign internships to improve the educational process.

As a result of the research, an insufficient technological and psychological readiness of students and teachers to change the educational process associated with an orientation towards independent work was revealed. There are problems associated with the lack of modern IT infrastructure of universities and low computer literacy of teachers.

The main reason for insufficient motivation of students for independent work and the development of creative potential is the low level of creativity of teachers.

All the identified problems are global issues and a serious obstacle to the organization of independent work of students; this fact should be taken into account when planning the educational process and shaping the personnel policy of higher educational institutions.

\section{CONCLUSIONS}

It was found that students are often poorly motivated to work independently (low motivation in $54.3 \%$ of the respondents in this group), they expect ready-made instructions and solutions. Nevertheless, the internal motivation for innovations in the educational process among students is higher than among teachers (found in $69.2 \%$ and $54.3 \%$ of respondents, respectively), which indicates the dissatisfaction of the former and the inertia of the latter.

Among the forms of independent work, routine formal methods of writing abstracts prevail (which was noted by about $90 \%$ of the respondents in both groups), and the indicators of research work are extremely low (up to $11.5 \%$ in the group of students). Teachers often feel that undergraduate students are not ready to do research, and 
students focus on specific "craft" professional skills rather than developing scientific thinking. This correlates with the data of scientific literature, which notes the lack of prestige and economic disadvantage of pursuing science among students. This study highlights the low level of use of educational websites $(39.1 \%$ in the teaching group and $48.1 \%$ in the student group), which may be due to low user qualifications, lack of awareness, quality of websites and relevance of the information provided.

Comparative analysis of goal-setting, motivation and self-government level of students and teachers using the psychodiagnostic method "Purpose-means-result" showed that, unlike teachers, students have more pronounced problems of setting goals, choosing means and assessing the result of educational activities. Despite the fact that the majority of teachers scored optimal scores, a significant part of them showed deviations from the average score, which may indicate professional burnout and raise questions about professional suitability and the need for an appropriate personnel policy in universities. Personal factors can become a serious obstacle to the introduction of innovative forms of the educational process.

Research using the Motivation for Success and Fear of Failure methodology has shown that students often associate negative motivation with the need to speak in front of an audience, that is, with the fear of public speaking, and distance learning eliminates this problem. At the same time, distance learning does not solve the essence of the problem. Therefore, such cases require psychological and pedagogical correction based on an individual approach to each student, for which an appropriate teacher qualification is required.

It was revealed that more than a third of the students in the study group have a weak will, many students find it difficult to plan their activities and manage time, they depend on external circumstances, are inconsistent and insufficiently motivated to achieve success, combined with biased self-esteem. In the group of teachers, on the contrary, high indicators of willpower, responsible behavior and adequate self-esteem were revealed.

Organization of independent work of students depends both on technological support and on the psychological readiness of students and teachers to introduce new approaches and methods of educational activity. The identified problems are a global and serious obstacle to the organization of students' independent work. This fact must be taken into account when planning the educational process and forming the personnel policy of higher educational institutions.

The gradual involvement of students in an independent creative process of scientific research under the guidance of a teacher is an effective tool for the development of important professional and personal qualities, the disclosure of a person's creative potential, an increase in enthusiasm for learning and interest in the profession.

\section{LIMITATIONS}

When assessing the implementation of new forms of independent work of students in the educational process, a number of teachers lacked objectivity, which was associated with 
the desire to show their educational institution and qualifications in the most favorable light. Some of the students also tried to perform better because of the fear that the results of the survey, despite the fact that it was anonymous, could indirectly affect their academic performance.

\section{RECOMMENDATIONS}

The introduction of innovative forms of work in the educational process based on the change in the student and teacher relationship, a competency-based approach and an increase in the importance of independent work imposes new requirements for the professional qualities of a teacher. Therefore, there is a need to improve the personnel policy of higher educational institutions; thus, when selecting personnel, they should be focused on teacher's creativity, the ability to rationally use working time, involvement in scientific research and willingness to attract students to this activity, lack of signs of professional burnout.

To prevent professional burnout of teachers, the leadership of higher educational institutions should pay attention to the comprehensive methodological support for creative pedagogical activities, maintenance of a safe moral and psychological climate in the team, improvement of teachers' working conditions and leisure time. It is also recommended to occasionally conduct psychodiagnostic tests and psychological correction based on the results obtained.

In order to ensure the compliance of teacher qualifications with modern requirements, to increase their motivational focus on creativity, research and the introduction of innovations, to improve communication with students, to establish interaction and feedback between the educational process participants, it is necessary to organize teacher trainings, scientific and methodological seminars, and international conferences to promote foreign internships and other forms of the exchange of experience.

It is necessary to develop various forms of independent work of students focusing on the implementation of creative tasks and research work. The independent work should be aimed at the gradual transformation of the student's negative attitudes to positive ones. At the same time, independent work should be carried out based on the constant interaction between the student and the teacher, who will help to plan the activity, critically and objectively assess the result, correct mistakes, and indicate the prospects for further research.

The identified problem of self-organization of students related to goal-setting, motivational focus, poor volitional qualities, and inability to use time rationally, indicates the need for the development of students' abilities to learn, conducting appropriate training, and placing the focus of curricula on the solution to this issue. Students should be taught the algorithm for performing independent work and the number of creative research tasks should be gradually increased.

\section{REFERENCES}

Abdullaeva, Sh. E. (2018). Innovative methods of teaching students in Uzbekistan. Retrieved 19 September, 2020 from http://library.ziyonet.uz/ru/book/24856 
Ahmed, T., Chandran, V. G. R., Klobas, J. E., Liñán, F., \& Kokkalis, P. (2020). Entrepreneurship education programmes: How learning, inspiration and resources affect intentions for new venture creation in a developing economy. The International Journal of Management Education, 18(1), 100327.

Altukhova, A. V. (2014). Independent Work of Students in the Context of Implementation of the Principle of Knowledge Strength in Secondary Schools of Ukraine of the Second Half of the XX century. Means of educational and research work, 42, 66-12.

Aziziy, Y. N., Marwoto, P., \& Iswari, R. S. (2020). Designing e-learning based independent learning activity unit through virtual worksheet: improving student's 4Cs. In Journal of Physics: Conference Series (Vol. 1567, No. 4, p. 042103). IOP Publishing.

Balatsky, A. V. (2016). The use of information and communication technologies in a creative educational environmen. Scientific Almanac, 5-2(19), 41-44.

Begus, K., \& Bonawitz, E. (2020). The rhythm of learning: Theta oscillations as an index of active learning in infancy. Developmental Cognitive Neuroscience, 45, 100810.

Bulaeva, M. N., Vaganova, O. I., Koldina, M. I., Lapshova, A. V., \& Khizhnyi, A. V. (2018). Preparation of bachelors of professional training using MOODLE. In E. G. Popkova (Ed.), The Impact of Information on Modern Humans (Vol. 622, pp. 406-411). Springer.

Cantor, P., Osher, D., Berg, J., Steyer, L., \& Rose, T. (2018). Malleability, plasticity, and individuality: How children learn and develop in context. Applied Developmental Science, 23(4), 307-337.

Carter, P., \& Darling-Hammond, L. (2016). Teaching diverse learners. In D. H. Gitomer, \& C. Bell (Eds.), Handbook of research on teaching (5th ed., pp. 593-638). Washington, DC: American Educational Research Association.

Chirva, A. N., \& Chirva, O. G. (2018). Contents and method of professionally oriented training of informatic disciplines of future teachers of technologies. Scientific Vector of the Balkans, 1, 27-31.

Croucher, G., \& Lacy, W. B. (2020). Perspectives of Australian higher education leadership: convergent or divergent views and implications for the future? Journal of Higher Education Policy and Management, 42(4), 516-529.

Cukurova, M., Bennett, J., \& Abrahams, I. (2018). Students' knowledge acquisition and ability to apply knowledge into different science contexts in two different independent learning settings. Research in science \& Technological education, 36(1), 17-34.

Denham, B. (2016). Teaching research methods to undergraduates. Journalism and Mass Communication Educator, 51(4), 54-62. 
Denworth, L. (2019). Debate Arises over Teaching "Growth Mindsets" to Motivate Students. Scientific American. Retrieved 19 September, 2020 from https://www.scientificamerican.com/article/debate-arises-over-teaching-growthmindsets-to-motivate-students/

Diamond, A., \& Daphne, S. L. (2016). Conclusions about interventions, programs, and approaches for improving executive functions that appear justified and those that, despite much hype, do not. Developmental Cognitive Neuroscience, 18, 34-48.

Fedorov, A. A., Paputkova, G. A., Ilaltdinova, E. Y., Filchenkova, I. F., \& Solovev, M. Y. (2017). Model for employer-sponsored education of teachers: Opportunities and challenges. Man, in India, 97(11), 101-114.

Fox, J. L., \& Diezmann, C. M. (2020). An analysis of teaching and learning partnerships in Australian universities: prevalence, typology and influences. Journal of Higher Education Policy and Management, 42(4), 404-423.

Garnevska, S. M. (2018). Opportunities for forming communication technology images in training in technology and entrepreneurship. Balkan Scientific Review, 1, 34-37.

Gregory, A., Clawson, K., Davis, A., \& Gerewitz, J. (2016). The promise of restorative practices to transform teacher-student relationships and achieve equity in school discipline. Journal of Educational and Psychological Consultation, 26(4), 325-353.

Hammond, Z. (2016). Culturally responsive teaching and the brain: Promoting authentic engagement and rigor among culturally and linguistically diverse students. Thousand Oaks, CA: Corwin.

Ho, E., Clarke, A., \& Dougherty, I.(2015), Youth-led social change: Topics, engagement types, organizational types, strategies, and impacts. Futures, 67, 52-62.

Jackson, A., \& Burch, J. (2019). New directions for teacher education: investigating school/university partnership in an increasingly school-based context. Professional Development in Education, 45, 138-150

Kamenez, N. V., Smirnova, Zh. V., Vaganova, O. I., Bystrova, N. V., \& Tsarapkina, J. M. (2019). Development of Instructing Techniques in Professional Training. International Journal of Mechanical Engineering and Technology, 10(2), 899-907.

Khamdullaeva, I. F., \& Garibyan, I. I. (2018). Modern methods of training specialists in the field of environmental safety in Uzbekistan. In Far East Spring -2018: Materials of the 16th International Scientific and Practical Conference on Environmental Safety (pp. 28-29). Komsomolsk-on -Amur, 2018.

Khodan, O. L. (2013). Competence approach to the training of future professionals in universities. Scientific Bulletin of Uzhhorod University: Series: Pedagogy. Social work, 29, 232-235.

Koliadenko, N. V. (2016). Psychology of creativity in design: textbook manual. Kyiv: National Academy of Management of Culture and Arts. 
Korpershoek, H., Harms, T., de Boer, H., van Kuijk, M., \& Doolaard, S. (2016). A meta-analysis of the effects of classroom management strategies and classroom management programs on students' academic, behavioral, emotional, and motivational outcomes. Review of Educational Research, 86(3), 643-680.

Kuznetsov, I. A., \& Katranov, S. N. (2016). Improving the effectiveness of independent learning in the process of extracurricular reading of professionally oriented literature in a foreign language by students of technical universities. Philological sciences. Questions of theory and practice, 4(58), 190-192.

Lazonder, A. W., \& Harmsen, R. (2016). Meta-analysis of inquiry-based learning: Effects of guidance. Review of Educational Research, 86(3), 681-718.

Lee, C. D. (2017). Integrating research on how people learn and learning across settings as a window of opportunity to address inequality in educational processes and outcomes. Review of Research in Education, 41(1), 88-111.

Love, S. L. (2018). Critical Thinking Creative Thinking Collaboration Communication. Mentorings Minds.

Lovekamp, W. E., Soboroff, S. D., \& Gillespie, M. D. (2016). Engaging students in survey research projects across research methods and statistics courses. Teaching Sociology, 45(1), 65-72.

Makhometa, T. M., \& Tiahai, I. M. (2018). The use of interactive learning in the process of preparing future math teachers. Balkan Scientific Review, 1, 48-52.

Markova, S. M., Sedykh, E. P., Tsyplakova, S. A., \& Polunin, V. Y. (2018). Perspective trends of development of professional pedagogics as a science. Advances in Intelligent Systems and Computing, 622, 129135.

McBurney, D. H. (2016). The problem method of teaching research methods. Teaching of Psychology, 22(1), 36-38.

Meier Jæger, M., \& Møllegaard, S. (2017). Cultural capital, teacher bias, and educational success: New evidence from monozygotic twins. Social Science Research, $65,130-144$.

Monson, R. (2017). Groups that work: student achievement in group research projects and effects on individual learning. Teaching Sociology, 45(3), 240-251.

Moroney, D., Newman, J., \& Osher, D. (2018). Out of school time programs. In D. Osher, D. Moroney, \& S. Williamson (Eds.), Creating Safe, Equitable, Engaging Schools: A Comprehensive, Evidence-Based Approach to Supporting Students (pp. 121134). Cambridge, MA: Harvard Education Press.

Mukova, L. A. (2016). Distance learning: socio-economic foundations and efficiency (based on the material of Bulgaria). Education Sciences. Economics, profession, business, 1, 82-88. 
National database of legislation (2019). Decree of the President of the Republic of Uzbekistan "On approval of the concept of development of the public education system of the Republic of Uzbekistan until 2030". No. 06/19/5712/3034.

Noguera, P., Darling-Hammond, L., \& Friedlaender, D. (2017). Equal opportunity for deeper learning. In R. Heller, R. Wolfe, \& A. Steinberg (Eds.), Rethinking readiness: Deeper learning for college, work, and life (pp. 81-104). Cambridge: Harvard Education Press.

Oakes, J., Maier, A., \& Daniel, J. (2017). Community schools: An evidence-based strategy for equitable school improvement. Boulder, CO: National Education Policy Center and Palo Alto, CA: Learning Policy Institute.

Osher, D., Cantor, P., Berg, J., Steyer, L., \& Rose, T. (2018). Drivers of human development: How relationships and context shape learning and development. Applied Developmental Science, 24(1), 6-36.

Osher, D., Kidron, Y., Brackett, M., Dymnicki, A., Jones, S., \& Weissberg, R. P. (2016a). Advancing the science and practice of social and emotional learning: Looking back and moving forward. Review of Research in Education, 40(1), 644-681.

Osher, D., Kidron, Y., DeCandia, C. J., Kendziora, K., \& Weissberg, R. P. (2016b). Interventions to promote safe and supportive school climate. In K. R. Wentzel \& G. B. Ramani (Eds.), Handbook of social influences in school contexts (pp. 384-404). Routledge.

Pennington, C. R., Heim, D., Levy, A. R., \& Larkin, D. T. (2016). Twenty years of stereotype threat research: A review of psychological mediators. PLoS One, 11(1), e0146487.

Picken, J., \& Springthorpe, L. (2019). 7 elements to building an effective knowledgebase. Elsevier. Retrieved 19 September, 2020 from https://www.elsevier.com/connect/7-elements-to-building-an-effectiveknowledgebase\#contributors

Poindexter, P. M. (2016). A model for effective teaching and learning in research methods. Journalism and Mass Communication Educator, 52(4), 24-36.

Psychological Tests (n.d.). A. Ya. Psychology: tests, trainings, dictionary, articles. Retrieved 19 September, 2020 from http://azps.ru/

Renninger, K., \& Hidi, S. (2017). The power of interest for motivation and engagement. New York: Routledge.

Romanovska, O. O., Romanovska, Ju. Ju., \& Romanovskyi, O. O. (2020). The experience of higher education in the United States of America in the 20-21st centuries. Book 4: Features of academic (university) entrepreneurship in the United States in the second half of the 20th-early 21 st century. 
Ruzieva, D. I. (2018). Impact of teaching staff training on the progressive development of Uzbekistan. Scientific result. Pedagogyandpsychologyofeducation, 4(1), 12-21.

Sanchez, M. A., \& Lidawan, M. W. (2020). Galvanizing Strategic and Independed Learning with Technologies. European Journal of Literature, Language and Linguistics Studies, 1, 7-10.

Shurygin, V. Y., \& Krasnova, L. A. (2016). Electronic Learning Courses as a Means to Activate Students' Independent Work in Studying Physics. International Journal of Environmental and Science Education, 11(8), 1743-1751.

Skurativska, S. P. (2013). Features of the Organization of Independent Work of Students. Retrieved 19 September, 2020 from https://osvita.ua/school/lessons_summary/ education/36615/

Smirnova, Zh. V., \& Krasikova, O. G. (2018). Modern tools and technologies for assessing learning outcomes. Bulletin of Minin University, 6(3), 9.

Smirnova, Zh. V., Gruzdeva, M. L., \& Krasikova, O. G. (2017). Open e-courses in educational activities. Bulletin of Minin University, 4(21), 3.

Smirnova, Zh. V., Vaganova, O. I., \& Trutanova, A. V. (2018). Final state certification as a way to comprehensive assessment of competencies. Karelian Scientific Journal, 6(3), 74-77.

Stafford-Brizard, K. B. (2016). Building blocks for learning: A framework for comprehensive student development. New York: Turnaround for Children.

Stolyarenko, T. L. (2014). Competence Approach to the Training of Future Economists. Means of educational and research work, 42, 120-128.

Taylor, R. D., Oberle, E., Durlak, J. A., \& Weissberg, R. P. (2017). Promoting positive youth development through school-based social and emotional learning interventions: A meta-analysis of follow-up effects. Child Development, 88(4), 1156-1171.

Tsyplakova, S. A., Grishanova, M. N., Korovina, E. A., \& Somova, N. M. (2016). Theoretical foundations of designing educational systems. Azimuth of scientific research: pedagogy and psychology, 5(1), 131-133.

Turkmenova, M. Sh., \& Babanov, Sh. Zh. (2020). Development of pedagogical creativity among teachers of physical education and sports as a pedagogical problem. Science, education and culture, 8(52), 1-2.

Vaganova, O. I., Odarich, I. N., Popkova, A. A., Smirnova, Z. V., \& Lebedeva, A. A. (2019). Independent work of students in professional educational institutions. Amazonia Investiga, 8(22), 295-304.

Vong, S. K., \& Yu, W. M. (2018). Is teacher education at risk? A tale of two cities Hong Kong and Macau. A Journal of Comparative and International Education, 48(5), 785-800. 